
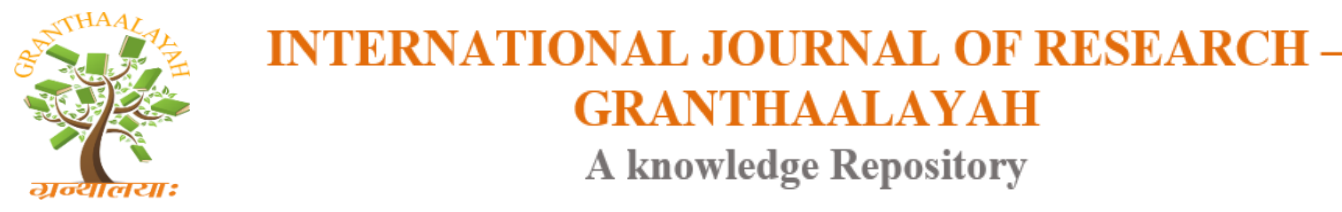

Science

\title{
THE EFFECT OF SOIL CONDITIONS ON THE PHYSIOLOGICAL INDICES OF Costus afer Ker Gawl
}

\author{
Etukudo Mbosowo M ${ }^{* 1}$, Simon Ebinimitei $\mathbf{C}^{2}$ \\ ${ }^{* 1,2}$ Department of Biology, Federal University Otuoke, P.M.B 126, Yenagoa, Bayelsa State,
}

Nigeria

\begin{abstract}
The effect of different soil conditions on some physiological indices of Costus afer was studied in two locations (Otuoke and Opolo) in Bayelsa State, Nigeria. The soils physico-chemical properties as well as mineral elements and phytochemical contents in leaf samples were assessed using standard procedure. The descending order of mineral elements in location I were, $\mathrm{P}>\mathrm{Ca}>$ $\mathrm{Mg}>\mathrm{K}>\mathrm{C}>\mathrm{H}>\mathrm{AI}>\mathrm{Na}>\mathrm{N}$, while that of location 2 were, $\mathrm{P}>\mathrm{Ca}>\mathrm{C}>\mathrm{K}>\mathrm{Al}>\mathrm{H}>\mathrm{Mg}>$ $\mathrm{Na}>\mathrm{N}$. The contents of calcium, magnesium, sodium, potassium, nitrogen and phosphorus in leaves of $\mathrm{C}$. afer in location I were significantly $(\mathrm{P}<0.05)$ higher than those of location 2 , while the iron, zinc and lead contents in leaves of the test plant in location 1 were relatively higher than that of location 2. There were also marked variations in phyto chemical contents in leaves of the test plant between the two locations. This study indicates that soil factors have a considerable influence on the mineral elements and phytochemical contents of Costus afer.
\end{abstract}

Keywords: Soil Conditions; Physiological Indices; Costus afer.

Cite This Article: Etukudo Mbosowo M, and Simon Ebinimitei C. (2018). "THE EFFECT OF SOIL CONDITIONS ON THE PHYSIOLOGICAL INDICES OF COSTUS AFER KER GAWL." International Journal of Research - Granthaalayah, 6(1), 362-367. https:// doi.org/10.29121/granthaalayah.v6.i1.2018.1630.

\section{Introduction}

The contents of nutrients in plants are affected by certain factors such as plant species, and varieties, total nutrient supply in soils and factors regulating their availability to plants (Brady and Weil, 2000, Smith and Smith, 1990). Physiological processes in plants such as respiration, assimilation, photosynthesis and metabolism are influenced by various climatic factors such as temperature, humidity, precipitation, light intensity and altitude (Agbede, 2009, Etukudo et al., 2015). It is important to note that the effects of these factors vary considerably from one nutrient element to another (Ames, 1997, Etukudo and Osim., 2018). According to Martinez-Ballesta et al., 2010, the contents of mineral elements present in plants are influenced by factors such as genetic properties of the crop species, climatic conditions, soil characteristics and the degree of maturity of the plant during harvest. The soil as a medium of plant growth consists of a mixture 
of minerals, organic matter, water, and air in different amounts, which influence the biochemical constituents of plants (Anoliofo, 2006, Ames, 1997). In addition, the constituents of organic matter, which include living organisms, excretory products, and decay products, have much influence on the physiological composition in plants (Ames, 1997, Apoxi et al., 2000).

Costus afer Ker Gawl of the Zingiberaceae family, commonly called bush sugar cane or monkey sugar cane (Nyananyo, 2006, Etukudo, 2003), is a monocot and a relatively tall, herbaceous, unbranched tropical plant with creeping rhizome. It is commonly found in moist and shady forest of West and tropical Africa (Nyananyo, 2006, Etukudo, 2003). C. afer is a perennial, rhizomatous herb that can attain a height of up to $4 \mathrm{~m}$, and is often planted in home gardens for medicinal purposes as well as widely used for ceremonial and religious purposes (Nyananyo, 2006, Etukudo, 2003). This study was carried out to examine the effect of different soil conditions on some physiological indices of Costus afer in two locations (Otuoke and Opolo) in Bayelsa State, Nigeria.

\section{Materials and Methods}

\subsection{Study Area}

This research was carried out in two locations (Otuoke-L1 and Opolo-L2) in Bayelsa State, Nigeria. Yenagoa is located at coordinates of $4^{\circ} 55^{\prime} \mathrm{N}$ and $6^{\circ} 15^{\prime} \mathrm{E}$, and Bayelsa State is situated in the heaviest rainfall area of Nigeria with a mean minimum monthly temperature that ranges from $25^{\circ} \mathrm{C}$ to $31^{\circ} \mathrm{C}$ (Niger Delta Source, 2014).

\subsection{Collection of Samples}

Soils and plant materials (leaves of Costus afer) were collected from the two locations, Otuoke(location 1) and Opolo- (location 2) in Bayelsa State.

\subsection{Analysis of Soil Samples}

The physico-chemical properties of experimental soil were analysed using standard procedures (A.O.A.C, 1999).

\subsection{Determination of Mineral Elements Contents of Plant Material}

Leaf samples of Costus afer were kept in polybags after washing with water and rinsing with distilled water. They were dried to a constant weight in an oven maintained at $60^{\circ} \mathrm{C}$. Plant materials were further crushed to powder form and stored in sample bottles for analysis. The powdered leaf samples were processed further by drying in an oven at $105^{\circ} \mathrm{C}$ for 2 hours, $1.0 \mathrm{~g}$ weighed into a platinum crucible and placed in a muffle furnace maintained at $400^{\circ} \mathrm{C}$. Ashing of the plant samples was done for 5 hours, followed by dissolving with $10 \mathrm{~cm}^{3}$ of $1 \mathrm{M} \mathrm{HCL}$, and filtration of the resulting solution through Whatman No. 1 filter paper into $50 \mathrm{~cm}^{3}$ volumetric flask. The resulting solution was made up to the required mark with distilled deionized water. The contents of mineral elements were determined using Atomic Absorption Spectrophotometer (Ano et al., 2007). 


\subsection{Analysis of Phytochemicals}

The dried and powdered leaf samples of $C$. afer were subjected to various sample preparation stages using standard laboratory procedures for determination of alkaloids, tannins, flavonoids, saponins and glycosides. Standard methods were used to determine the alkaloid [Harbone, 1973], tannin [Pearson, 1976], flavonoid [Bohn and Kocipai-Abyazan, 1994] and saponin [Obadoni and Ochuko, 2001] contents of the test plant.

\subsection{Statistical Analysis}

Analysis of variance (ANOVA) was used for analysis of Data obtained from the study. Least significant Differences (LSD) was used to test the differences in the means (Obi, 2003).

\section{Results and Discussions}

\subsection{Results}

The morphological and physical properties of soil in the two sampling locations are presented (Table 1). Soil samples from the two locations were assessed at $0-20 \mathrm{~cm}$ depth. The dark greyish brown coloured soil of location 1 had a granular structure with loamy sand textural characteristics, while soil of location 2 had a yellowish brown colour with a sub-angular blocky structure and sandy loamy textural characteristics (Table 1). The soil $\mathrm{pH}$ at location 1 and 2 were 5.10 and 4.90, respectively. The corresponding descending order of mineral elements were $\mathrm{P}>$ $\mathrm{Ca}>\mathrm{mg}>\mathrm{K}>\mathrm{C}>\mathrm{H}>\mathrm{Al}>\mathrm{Na}>\mathrm{N}$ for soil of location 1 , and $\mathrm{P}>\mathrm{Ca}>\mathrm{C}>\mathrm{K}>\mathrm{Al}>\mathrm{H}>\mathrm{Mg}>$ $\mathrm{Na}>\mathrm{N}$ for soil of location 2 (Table 1).

There were significant differences $(\mathrm{P}<0.05)$ in contents of calcium magnesium, sodium, potassium, nitrogen and phosphorus in leaves of Costus afer between location 1 (23.01, 12.73, $27.60,16.63,3.87$ and $0.62 \mathrm{mg} / 100 \mathrm{~g})$ and location $2(20.26,10.19,23.72,12.49,1.27$ and 0.43 $\mathrm{mg} / 100 \mathrm{~g}$ ), respectively. These values recorded in leaves of the test plant in location 1 were relatively higher than those of location 2 (Table 2).

The alkaloid, flavonoid, saponin and glycoside contents in leaves of $C$. afer in location 1 were significantly $(\mathrm{P}<0.05)$ higher than those of location 2 , while the tannin content in leaves of the test plant in location 2 was relatively higher than that of location 1 (Table 3 ).

Table 1: Soil physico-chemical properties in the two locations

\begin{tabular}{|l|l|l|}
\hline Soil properties & Location 1 & Location 2 \\
\hline Depth $(\mathrm{cm})$ & $0-20$ & $0-20$ \\
Mottle & None & None \\
Colour & Very dark greyish brown & Yellowish brown \\
Structure & Granular & Sub-angular blocky \\
Clay $(\mathrm{g} / \mathrm{kg})$ & $38.00 \pm 0.21$ & $48.00 \pm 0.27$ \\
Silt $(\mathrm{g} / \mathrm{kg})$ & $152.00 \pm 0.33$ & $188.00 \pm 0.20$ \\
Sand $(\mathrm{g} / \mathrm{kg})$ & $810.00 \pm 0.12$ & $765.00 \pm 0.26$ \\
Textural class & Loamy sand & Sand loam \\
\hline
\end{tabular}




\begin{tabular}{|l|l|l|}
\hline $\mathrm{pH}$ & $5.10 \pm 0.72$ & $4.90 \pm 0.36$ \\
Organic carbon $(\%)$ & $1.98 \pm 0.44$ & $1.49 \pm 0.60$ \\
$\mathrm{~N}(\%)$ & $0.136 \pm 0.12$ & $0.122 \pm 0.40$ \\
$\mathrm{P}(\mathrm{mg} / \mathrm{kg})$ & $9.12 \pm 0.17$ & $5.18 \pm 0.24$ \\
$\mathrm{Ca}(\mathrm{Cmol} / \mathrm{kg})$ & $3.62 \pm 0.33$ & $2.27 \pm 0.21$ \\
$\mathrm{Mg}(\mathrm{mg} / \mathrm{kg})$ & $2.49 \pm 0.40$ & $0.50 \pm 0.20$ \\
$\mathrm{Na}(\mathrm{mg} / \mathrm{kg})$ & $0.39 \pm 0.22$ & $0.23 \pm 0.10$ \\
$\mathrm{~K}(\mathrm{mg} / \mathrm{kg})$ & $2.07 \pm 0.59$ & $1.48 \pm 0.27$ \\
$\mathrm{H}(\mathrm{mg} / \mathrm{kg})$ & $0.82 \pm 0.06$ & $0.62 \pm 0.03$ \\
$\mathrm{Al}(\mathrm{mg} / \mathrm{kg})$ & $0.43 \pm 0.04$ & $0.63 \pm 0.02$ \\
\hline
\end{tabular}

Mean \pm standard errors from 3 replicates

Table 2: Mineral elements in leaves of Costus afer from the two locations

\begin{tabular}{|l|c|c|}
\hline Mineral elements (mg/100g) & Location 1 & Location 2 \\
\hline Calcium & $23.01 \pm 0.16$ & $20.26 \pm 0.10$ \\
Magnesium & $12.73 \pm 0.24$ & $10.19 \pm 0.43$ \\
Sodium & $27.60 \pm 0.39$ & $23.72 \pm 0.49$ \\
Potassium & $16.63 \pm 0.22$ & $12.49 \pm 0.36$ \\
Nitrogen & $3.87 \pm 0.17$ & $1.27 \pm 0.20$ \\
Phosphorus & $0.62 \pm 0.05$ & $0.43 \pm 0.07$ \\
Iron & $0.24 \pm 0.02$ & $0.32 \pm 0.07$ \\
Manganese & $0.044 \pm 0.01$ & $0.030 \pm 0.02$ \\
Copper & $0.022 \pm 0.01$ & $0.017 \pm 0.03$ \\
Zinc & $0.56 \pm 0.02$ & $0.73 \pm 0.04$ \\
Lead & $0.002 \pm 0.01$ & $0.004 \pm 0.01$ \\
\hline
\end{tabular}

Mean \pm standard error from 3 replicates

Table 3: Phytochemicals in leaves of Costus afer from the two locations

\begin{tabular}{|l|c|c|}
\hline Phtochemicals (\%) & Location 1 & Location 2 \\
\hline Alkaloids & $34.00 \pm 0.27$ & $30.14 \pm 0.46$ \\
Tannins & $23.00 \pm 0.52$ & $26.46 \pm 0.21$ \\
Flavonoids & $20.26 \pm 0.77$ & $18.24 \pm 0.59$ \\
Saponins & $12.04 \pm 0.10$ & $16.20 \pm 0.33$ \\
Glycosides & $11.08 \pm 0.41$ & $8.12 \pm 0.20$ \\
\hline
\end{tabular}

Mean \pm standard error from 3 replicates

\subsection{Discussion}

Soil structure has a strong influence on plant growth and nutrient distribution in the soil as indicated in this study. There is a strong relationship between soil aggregation and soil nutrient such that good soil aggregation is related to the amount of useful organic matter and to biological processes in the soil (Ames, 1997, Agbede, 2009). Poor compaction in soil reduces plant growth and decreases uptake of nutrients by plants as well as distorts root growth and activity due to insufficient aeration and mechanical destruction (Cox, 1990, Smith and Smith, 1990). Thus, the efficient absorption of nutrients by plants roots is restricted due to partial root contact with soil particles and the soil solution. The soil texture also has greater influence on the amount of air, 
water and nutrients held in the soil. In soils where large particles of sand dominate, the penetration of air, water and roots occurs much more readily through the soils (Agbede, 2009, Brady and Weil, 2002, 2000, Ames, 1997). Therefore, these may have contributed to the differences in nutrients in the test plant between the two locations.

Differences in $\mathrm{pH}$ may also contribute to variation in nutrients and phytochemicals in plants. Soil $\mathrm{pH}$ is known to vary in time and space, and has a major influence on solubility and availability as well as potential phytotoxicity of metals (Atwell, 1999, Etukudo and Osim., 2018). The availability of nutrient elements is strongly affected by soil $\mathrm{pH}$, such that magnesium and zinc contents of plants decreases greatly with increasing pH (Anoliofo, 2006, Pajevic et al., 2004). Differences in soil moisture conditions may also bring about variation in the contents of nutrients and phytochemicals between the two locations. A dry soil reduces nutrient adequacy for plant use while waterlogged soils affect the transformation of nutrients (Ames, 1997, Brady and weil, 2000). In waterlogged soils, nutrients such as phosphorus, nitrogen and oxygen becomes limiting, and gases such as carbon iv oxide can accumulate to toxic levels in the soils (Ames, 1997, Agbede, 2009). Similarly, differences in content of organic matter may also leads to the variation in the plant content of elemental nutrients. This is because organic matter act as a storage medium for soil nutrients, supply food for decomposers of soil organic material and replenishes the soil fertility (Ames, 1997, Etukudo et al., 2015).

\section{Conclusions and Recommendations}

There were marked variations in mineral element and phytochemical contents of Costus afer between the two locations. This study indicates that soil factors have a considerable influence on the mineral element and phytochemical contents of Costus afer.

\section{Acknowledgements}

We wish to appreciate the contributions from Mr. Sunday Okpata, Department of Biology, and Mr Awolabi Akeem, Department of Biochemistry, Faculty of Science, Federal University Otuoke, Bayelsa State, Nigeria.

\section{References}

[1] Brady, N.C., and Weil, R.R. The Nature and Properties of Soils. 13th ed. Upper Saddle River, NJ., Pearson Education, 2002.

[2] Smith, R.L., and T.M. Smith. 1990. Ecology and Field Biology. Upper Saddle, River, NJ. Pearson Education, 1990.

[3] Agbede, O.O. Understanding Soil and Plant Nutrition. Nigeria: Salmon Press and Co. Ltd, 2009, 20-60.

[4] Etukudo, M.M., Hamilton-Amachree, A., and Roberts, E.M.I. Eco-physiological Studies of Elementalnn and Proximate Contents of Gnetum africanum Welw and Telfairiaoccidentalis Hook seeds from two Ecological Zones of Akwa Ibom State. European International Journal of Science and Technology. 4(6), 2015, 47-53.

[5] Ames, I.A. Effect of soil Quality on Nutrients Efficiency. United States Department of Agriculture. Natural Resources Conservation Service Soil Quality Institute. Technical Note, 4, 1997, 1-2. 
[6] Etukudo, M.M. And Osim, S.E. Nutritional And Phytochemical Studies Of Jatropha Tanjorensis Ellis \& Saroja Under Varied Soil Conditions. International Journal of Advance Research, 6(1), 2018 506-510.

[7] Martínez-Ballesta, M.C., Dominguez-Perles, R., Moreno, D.A., Muries, B., Alcaraz-López, C. et al., Minerals in Plant Food: Effect of Agricultural Practices and Role in Human Health. A review. Agron. Sustain. Dev. 30, 2010, 295-309.

[8] Anoliefo, C.O. Introductory Tropical Plant Biology. Uniben Press, Nigeria, 2006, 257- 362.

[9] Apoxi, S.O., Long, R.J., Castro, F.B and Orakor, E.R. Chemical Composition and Nutritive Value of Leaves and Stems of Tropical Weeds. Grass and Forage Science, 5(1), 2000, 77-81.

[10] Nyananyo, B.L. Plants from the Niger Delta. Nigeria, Onyoma Research Publications, 2006.

[11] Etukudo, I. Ethnobotany: Conventional and traditional uses of plant, the verdict press, Uyo, Akwa Ibom State, Nigeria, 1, 2003.

[12] Niger Delta Source: Bayelsa State. (2014). http://nigeriadeltasource.com/bayelsa

[13] A.O.A.C., Association of Official Analytical Chemist. Methods of analysis (16h Edition), Washington DC., U.S.A.1999

[14] Ano, A.O., Odoemelam, S.A. and Ekwueme, P.O. Lead and Cadmium Levels in Soils and Cassava (Manihot esculenta Crantz) along Enugu- Port Harcourt Express Way in Nigeria. Electronic Journal of Environmental, Agricultural and Food Chemistry.6 (5), 2007, 2024 - 2031.

[15] Harbone, Z.B. Phytochemical Methods: A Guide to Modern Techniques of Plant Analysis, Chapman and Hall, London, 1973, 113 - 185.

[16] Pearson, D. Chemical Analysis of Foods. (7th Ed), Henry Edward company, Churchchill, Livingstone, London, 1976, 218- 336.

[17] Bohn, B.A. and Kocipai-Abyazan, R. Flavonoids and Condensed Tannins from the Leaves of Hawaiian Vaccinium vaticulatum and V. calycinum. Pacific Science, 48, 1994, 458-63.

[18] Obadoni, B.O. and Ochuko, P.O. Phytochemical Studies and Comparative Efficiency of the Extracts of Some Homoeostatic Plants in Edo and Delta States of Nigeria. Global Journal of Pure and Applied Sciences, 8, 2001, 203-08.

[19] Obi, 1.U. Statistical Methods of Detecting Differences between Treatment Means and Research Methodology Issues in Laboratory and Field Experiments. Nigeria, AP Express publishers limited, 2002.

[20] Cox G. Laboratory Manual of General Ecology, $6^{\text {th }}$ Ed. D. Ubugue, Iowa: William C. Brown Publishing. 1990.

[21] Atwell, Brian J., Kriedemann, Paul E. and Turnbull, Colin G.N. Plant in Action, Adaptation in Nature, Performance in Cultivation. Melbourne, Australia, Macmillan Education Australia Pty Ltd, 1999.

[22] Pajevic, S., Vasic, D., and Sckulic, P. Biochemical characteristics and Nutrient content of callus of sunflower inbred lines. Helia, 27 (41), 2004, 143-150.

\footnotetext{
*Corresponding author.

E-mail address: mbosombosowo@ yahoo.com
} 